\title{
オープン・ソース・ハードウェアを活用した 学び方を学ぶ組込みソフトウェア教育
}

An Education Program on Embedded Software Development Using Open

Source Hardware Aiming to Learn How to Learn New Technologies

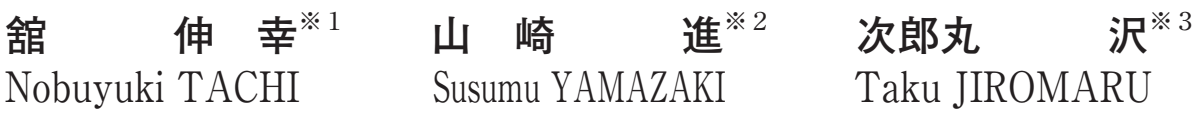

We have developed a course that trains graduate students as embedded software engineers. It is important for students to learn how to learn software technologies. Because they evolve rapidly and become obsolescent quickly. The students learn how to collect and read technical references and how to develop software. So far, 36 graduate students have completed this course. In exit questionnaires, 29 of the 36 students viewed the course positively. The students who had negative opinions had low programming skills before attending this course. In future work, we will improve the course and student satisfaction by measuring and adapting course content to their skill levels.

Keywords : Embedded Software Engineering Education, Instructional design

キーワード : 組込みソフトウェア工学教育, 授業設計, インストラクショナル・デザイン

\section{1.はじめに}

ソフトウェア開発技術は，単にコンピュータの制御 というだけでなく，今やあらゆる産業の競争力を決め うるものとなっている ${ }^{1)}$. かかる状況下，経済産業省 による組込みソフトウェア産業実態調査によれば，事 業責任者が政府の施策として期待する項目として「ソ フトウェアの開発を担う人材の育成」を 1 位に挙げた 人が最も多い ${ }^{2)}$.

一口に人材育成と言うものの，ソフトウェア開発と いう分野は, a ）きわめて技術進歩が速い，b）適応分 野が多様である，c）解決すべき問題はいつも技術的 に新規性が高いといった特徴がある。このため，技術 者は常に新しい技術や知識を自ら学び続ける必要があ る。つまり，教えられることに期待することなく，自 ら学ぶ能力を必要とする。たとえば中島は ${ }^{3)}$,「何かが 得意な人」と,「何かを学ぶのが得意な人」の違いと 題して, 『「何かを学ぶのが得意な人」というのは, 変 わりゆくIT産業の中で, 常にスキルや知識をバージョ ンアップし続けながら仕事をしています。この素養を 持っているプログラマーこそが，「良いプログラマー」 なのだ』と述べている.

本研究では, この「何かを学ぶ」能力に関し, 不足 する知識をどのようにすれば自力で学び修得すること ができるかという,「学び方を学ぶ能力」を身につけさ

2014 年 4 月 30 日受付

※1名古屋大学

※2 北九州市立大学

※3株式会社 OME
せる教育を目的とした。

まず 2 で学習目標と評価基準を述べ， 3 でハードウ エアと開発課題の詳細を，4で指導方略を，5で具体 的演習内容を述へ， 6 で実施結果を示し， 7 で考察を 行って, 8で本稿をまとめる.

\section{2. 学習目標}

本コースは, 教材設計マニュアル ${ }^{4)}$ を参考に設計を 行った. 以下に, 詳細を述べる。

\section{1 前提条件}

学習対象者は, 情報技術系の大学院 1 年生とした. 彼らは, ソフトウェア開発に関わる基礎的な知識, す なわちC 言語によるプログラミングや, UMLによるモ デリングについては学習済みであり, それを参加の前 提条件としている.

一方で，実践的なソフトウェア開発，特に組达み分 野のプログラム開発の経験については, 必要なスキル 条件としていない.

\section{2 行動目標}

一般にソフトウェア開発の実習授業などでは, 開発 環境は教師側が準備をする。また，前提条件となる八 ードウェア仕様等は, 明文化した資料としてこれも教 師側が配付する。 しかしそれでは, 特定のアプリケー ションの作り方を学ぶだけとなる可能性がある.また, 社会における業務では, 開発環境や必要な情報は, 開 発者自身が準備したり調查したりする必要がある。こ のような力をつけるためには, 問題解決に必要なルー ルや手順を自ら発見したり考案したりする，「学び方」 
を修得する必要がある。そこで, 本教育の行動目標を つぎのように設定した。

『与えられた要求仕様を満たすソフトウェアを, 教師の最小限の支援を受けて，

自分なりに工夫して

要素技術を統合し開発することによって

問題解決に必要なルールや手順を自ら編み出せる こと』

\section{3 評価条件}

学生は， 2 名から 3 名でチームを組み，チーム内で 相談しあうことができる。また，インターネットを利 用して，必要な情報を入手することができる，教師に 対しての質疑も許されるが, 自力で調査可能な情報は 回答されない.

\section{4 合格基準}

図 1 に本研究での教育コース（以下，本コース）で 扱う開発プロセスを示す。

これは，ウォーターフォール・モデルに基づいた一 般的なプロセスである。本コースでは，開発プロセス を構成する工程ごとに，合格基準を設定した。この中 から本論文では, 図 1 で網掛けとしている部分である, 「要求分析のうちハードウェア (実行環境)に関する もの」と,「開発環境構築」の, 2 つの作業に扔ける学 習ついて詳細を述べる。 それぞれについての合格基準 は，以下のように定めた。

a . 要求分析のうち, ハードウェアに関するもの

a 1. 使用するマイコンについて, 必要なドキュメ ント（ユーザーズ・マニュアル）を入手する.

a 2. マイコンボードの仕様や回路図を入手する.

a 3. a 2 に基づいて, 教材（マイコン基板 $+\mathrm{LED}$ ) の, LEDやスイッチの接続先を調べる.

b．開発環境構築に関するもの

b 1. 使用するマイコンのプログラム開発に必要な

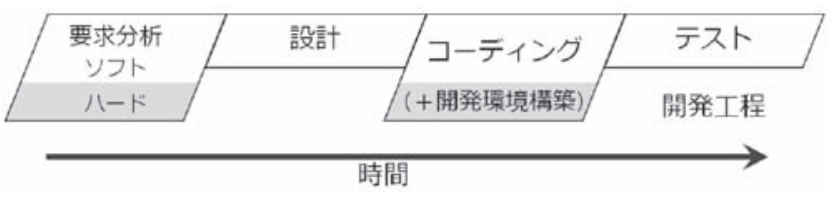

図 1 開発工程と本論文での解説工程

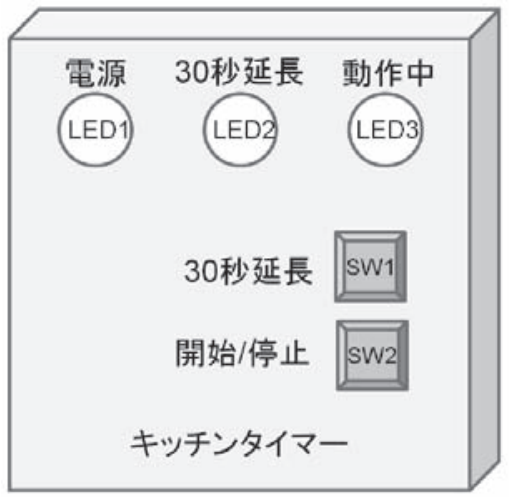

図 2 開発課題のイメージ

\section{ツールを入手する}

b 2. 入手したツールをインストールする.

b 3. 簡単なサンプルプログラムを作って, 開発環 境を使えるようにするとともに，ハードウェア分 析結果の正しさを調べる

\section{3. 開発課題と使用するハードウェア}

開発課題のソフトウェアは, キッチンタイマとした. 図 2 に，そのイメージを示す.

動作仕様の概要は，次のようなものである，通電す るとLED 1 が点灯する. SW 2 を押下すると時間計測 を開始し, LED 3 が点滅する。基本計測時間は30秒で ある. SW 1 を押下すると, 基準時間より 30 秒延長とし (計測時間は 1 分になる), LED 2 が点灯する。時間を 計測し終わると, 決められたパターンでLED 3 が点滅 して知らせる．計測中にSW 2 を押下すると計測を中 断する.

次に，使用するハードウェア（マイコンボード）に ついて説明する。図 3 に全体像を示す。

右側はV850という沉用のマイコンを使った，市販 のマイコン評価ボードである。 これに, プログラムの 実行結果を表示するためのLEDを 3 つ接続している. LED の接続には，ユニバーサル基板を使っている。 ま た，マイコン基板上には，プログラムの入力に使うプ ッシュ・スイッチが 2 個搭載されている.

このマイコンボードは, 仕様や回路図が公開されて いるオープン・ソース・ハードウェアである. その一 方で，あまり市場で知られておらず，単純な検索では 情報を発見しにくい．また，コピー\&ペーストで結果 を得られるような応用例は流通していない。この特徵 は, 今回のような教育の教材に大変適した性質である.

開発環境については，ボードメーカではなく，マイ コンメーカのサイトで公開されており, こちらもオー プンである.

一口にハードウェアと言っても, マイコンボードと マイコンは異なる物であり, 単純に 1 力所ですべての 情報を得ることはできない.このことを知ることもま た, 学び方を学ぶことに通じ, 本コースの目的に適し ている。

このように本コースでは, オープン・ソース・ハー

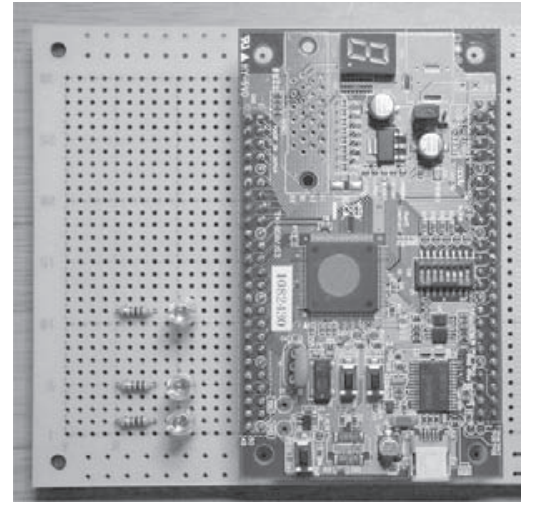

図 3 使用するマイコン基板 
ドウェアのマイコンボードを用い, ハードウェアもソ フトウェアも,とてもシンプルなものである。これは, 本コースの主たる目的が，単に「プログラムを作るこ と」ではないためである. 開発課題そのものは, 組达 みソフトウェアの特徵的かつ基本的処理である, 入力, 出力, 時間管理といったものを網羅しつつ, できるだ けシンプルなものを目指した。

\section{4. 指導方略}

学生には，必要な情報は何かを考えるところから始 めさせ，それについて調へ，そして入手し，利用する という, 主体的な問題解決活動を体験させる.これに より，不足する知識が何かを把握し，それをどのよう にすれば学び修得することができるかという，学び方 を学ぶ能力を身につけさせる.

マイコンボード（ハードウェア）は配布するが，与 える情報は使用マイコンの型番など最小限とした，学 生らは, プログラムを開発するには何が必要かを考え, ハードウェア環境から情報を読み取り, 必要な資料を 探して入手し,さらにプログラムの開発環境さえも自 力で構築することが求められる.これにより, 未知の 技術が要求される課題を, 自力で解決する体験をし, どのようにしたら未知の問題を解決していけるかとい う「学び方」を学ぶ.

図 4〜6に学習階層図を示す. 図 4 は, 学習戦略を ソフトウェアの開発プロセスに沿って定義したもので ある. a. 要求分析する, b. 設計する，c．プログラム を作る，d.動作を確認するの，4つの工程を定義して いる.

教師は, 基本的にこのプロセスを進めるマネジメン

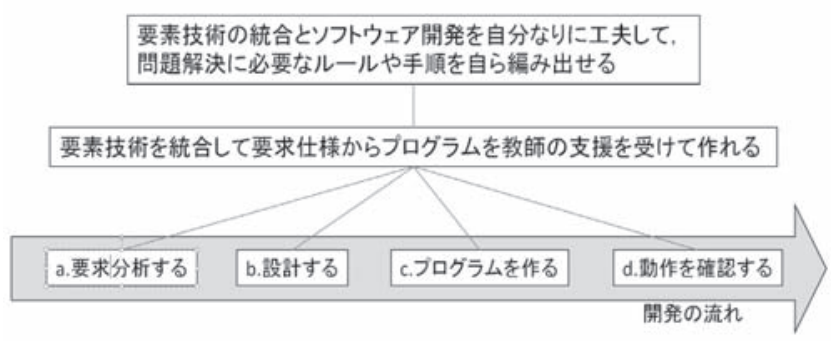

図 4 開発プロセスに則ったプログラム作成

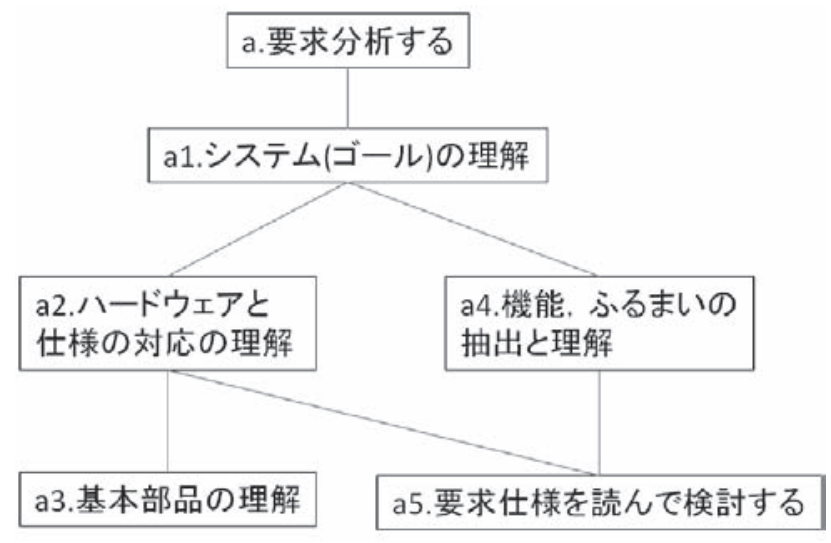

図 5 要求分析の学習階層
トと,いくつかの小さなヒントを出すことだけを行う． 学生らは不明点について, メンバ同士で相談をしたり, あるいは教師に対して適切な質問を行ったりすること で，作業を進めていく，教えてもらうではなく，わか らないことは, 聞く, 調べるという主体的行動を通し て, 自分なりの学ぶ方法を編み出していく.

本研究では, 図 4 に示した $\mathrm{a}$ から d の各工程につい て学習階層を設計しているが, 本論文ではこのうち $\lceil\mathrm{a}$. 要求分析する」と，「c．プログラムを作る」につ いて詳細を述へ，それら以外は省略する。

図 5 は, 「 $\mathrm{a}$. 要求分析する」における学習階層であ る. 要求分析にはまず,「 「 a 1. システム (ゴール) の 理解」が必要である。 システムはハードウェアとソフ トウェアから構成されており, その両方について分析 する必要があるからである.

作業環境が整えられた学習 (演習) では, ソフトウェ アの作成にのみ注意がいきがちである。一方で, 本コ 一スのような最小限のヒントと材料（教材）のみの場 合, 学生は前述のようなハードウェアとソフトウェア 両方の分析の必要性に容易に気づく。なぜなら, LED をひとつ点灯させるにも, スイッチの状態を調べるに も, ハードウェアの仕様がわからないとプログラムを 設計しょうがないからである。 このことは逆に, 何ら かのシステムが, ハードウェアとソフトウェアからで きているという組込みシステムにとっての基本的な概 念の理解にもつながる.

「a 2.ハードウェアと仕様の対応の理解」では, た とえば要求におけるLED 1 というランプが, 実際の八 ードウェアではどの部品にあたるのか. そしてその部 品は, マイコンのどこに接続しているのか. どうすれ ば点灯するのか，といったことを分析する。

「a 3 . 基本部品の理解」では, さらに一歩踏み込 んで, LEDやスイッチの動作原理について理解を深め る。単にプログラムを作るにあたっては不要とも言え るが, トラブルなどが起こった時に, 基本原理を知っ ておくことが役立つことを学ぶ.

たとえば有名なトラブルに, スイッチのチャタリン グがある，スイッチの原理を知っていれば，容易に現 象について納得でき，また対策も考案しやすい。これ は, 本コースを進める中でも, ほとんどの学生が現実 に体験する例である，ハードウェアにまつわるトラブ ルを効果的に回避したり対策したりするには, 動作原

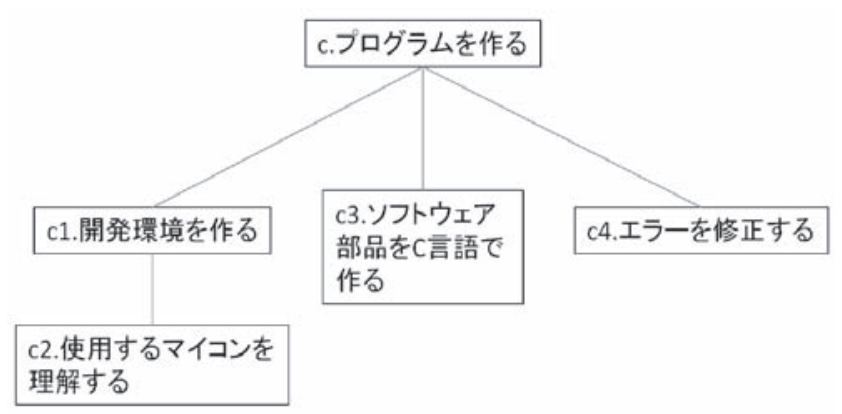

図 6 プログラム作成の学習階層 
理や，さらには関連する物理現象まで学んでおくこと が役立つ。これは，ハードウェアを扱うプログラムに 関する，「学び方を学ぶ」ひとつの例である.

$\lceil\mathrm{a} 4$. 機能, ふるまいの抽出と理解」は, 一般的な ソフトウェアの要求分析にあたる.

a 2 で要求の持つハードウェア面の要素を, a 4 で ソフトウェア面の要素を分析したことにより, a 5 で 文書としての要求仕様を読解し検討することができる に至る.

次に図 6 は,「 「 . プログラムを作る」に関する学習 階層である。ここには， c 1 . 開発環境を作るという 大切な作業がある. 先にも述べたが，一般的な授業で は, 開発環境は教師によって準備されている。しかし 仕事の現場では, 自分で構築しなければならない。こ れは「問題解決に必要なルールや手順を自ら編み出す」 ことが必要とされる典型的な例のひとつである。

分析結果などの工程産物は, 作業ミスや勘違い等に よる不確定要素を持つ。また, 開発環境に代表される ッール類は慣れが必要であり, これも以降の作業にお ける一種の不確定要素となる。

学生は, 不確定要素の存在を認識するとともに, どの ようにすればそれを以降の工程に持ち越さずに済むか を学ぶ.ここで， c 2 に扔ける一連の作業もまた，教 師が確認方法を指示したりはしない，学生は自ら確認 のルールや手順を考え, 実行する. つまり, 一見 c 1 の補助作業的に見える c 2 も, 学び方を学ぶ重要なし かけとして作用する。

開発環境の動作を確認し，ハードウェアの使い方も 理解できたところで,「 c 3.ソフトウェア部品を C 言 語で作る」という，コーデイング作業へ進む．本論文 では省略したが，本コースでは設計においてUMLを 用いて記述している。ここで言うソフトウェア部品と は, 設計において定義された処理単位のことを指す。

最後に,「 c 4.エラーを修正する」で文法的エラー を取り除いて，プログラミング工程を終える。

\section{5. 具体的演習方法}

次に具体的な演習方法に関し, 開発環境構築とハー ドウェア分析について述べる.

\section{1 開発環境構築}

教師は, 最小限のヒントとして, CPU名と, マイコ ンボード上のメーカ名(多くの市販マイコンボードは, ボード上にメーカ名がシルク印刷されている）の場所 のみを学生に伝える.

学生は, マイコンボードのメーカ名から, 比較的容 易にマイコンボード・メーカのWebページにたどり着 く. しかしそこにはきわめて似通った類似品が多数存 在するため, 他方のヒントであったCPU名とともにぺ ージ内から目的の製品を探す必要がある.

一般にマイコンにはファミリと呼ばれる多数の類似 製品が存在する．型番が少し異なるだけで大きく仕様 が異なる場合もあり，業務ではその誤認識によるトラ
ブルも実際に存在する. 本コースの受講学生の中にも, 誤認識によって誤った資料を入手してしまう例が毎回 1 ～例あった.

学生らは，ミスを犯したのが自分か他人かに関わら ず，多数の類似品があることや，それによるミスがあ りうることを体験する。これは，与えられた学習環境 で行う開発演習では得られない知見である。

目的の製品のWebページからは, 製品のドキュメ ントをダウンロードすることができる. 今回の製品で は, このドキュメントに開発環境のインストール方法 が詳しく記述されている。学生はそれに従い, 今度は マイコンメーカのWebサイトから, 必要なファイルを 探す。ここにも，同様に多数のファミリ製品の情報が 溢れているが, 再度ミスを犯す学生は, 少なくともこ れまで出ていない。これは，マイコンボードの情報を 得る時に, マイコンという製品カテゴリに関する情報 の探し方（それは学び方の一種とも言える）を学んだ ことを活かせているためと考えられる.

学生は, いくらかの苦労を伴いながらも, 開発環境 のインストールを完了する.これに関しては, 学生は 日頃からパソコンの「扱い方を学んでいる」ため, 特 に問題は起こらない.

\section{2 ハードウェア分析}

一般に, 設計工程において分析は最初の要求分析で 実施する. 本コースでは, 要求仕様書にはハードウェ アに関する情報を記載していない。このため, 要求分 析〜設計では，使用するハードウェア・リソースが何 か，までしかできない，実際のプログラムを作る時点 になって, はじめて学生は情報が不足していることに 気づく，たとえばLED は，マイコンのリソースのどこ を動かせば点灯するのか. またスイッチは，どこを読 めば状態を知ることができるのかといった，具体的情 報の必要性にようやくここで気づく.

社会に扔ける業務では, 通常このようなことはなく, マイコンのリソースへの割り当ても仕様書で明示され るのが通常である. しかし, それは完璧であることは むしろまれで, そのために後工程になってからミスや 手戻りが発生する事例は, 枚挙にいとまがない.この 原因のひとつは, 特に経験の少ない技術者の, 組込み ソフトウェア開発において, ハードウェア・リソース の扱いがきわめて重要な情報であることへの, 認識の 甘さがある。

学生は, プログラミング直前になって重要な情報が 不足していることに直面することからもまた, 組込み ソフトウェアの開発のしかたの学び方に扔ける大切な 点を学ぶことができる.

ここで質疑を行わせて, 教師が情報を与えることも 可能であるが, 本コースでは自力解析を行わせている. それは次のような理由からである。

組込みソフトウェア開発は, ハードウェアの制御と 密接な関わりを持つことが多い.このためたとえば, 回路図などを，書けないまでも読めるという，ハード 
ウェア情報への「アクセスのしかたを学んでおく」こ とは，将来大きなアドバンテージとなるのである，田 中ら ${ }^{5)}$ は, 「組达みソフトゥェア技術者には, 通常の情 報技術者より広い分野の知識と技術が求められる」と して, ハードウェアの知識を持つ組込みソフトウェア 技術者の育成について論じている。

対象がハードウェアという未知の世界であっても, どうすれば必要な情報を得ることができるかという， 「方法」を学ばせる。これは, 本コースの主目的である 「学び方を学ぶ」ことの主軸である.

具体的手順を述べる．先にダウンロードしてあるマ イコンボードのドキュメントには, 最終ページに回路 図が記載されている。最初，ほとんどの学生ははじめ ての回路図に当惑する。ここで教師は，これは一種の 地図であることを説明する，工場や消防署，果樹園や 水田，そして道路がある代わりに，さまざまな電子部 品の場所と，それらをつなぐ電線の道路があるといっ たふうである.この例示は効果的で，学生は読めそう だという気持ちになる。

次に，探すべき建物（部品）はなにかを学生に述べ させ, スイッチとLEDであることを確認させる．ここ で教師は，スイッチにはそれを示す記号があることを 伝える。ちょうど，地図上で「市役所が○であるよう に」である. しかし，どのような記号かは教えない． すでに学生は, 必要な技術情報を得る方法をこれまで の過程で学んでいるはずだからである.

学生はスイッチの記号を探し出し, 今度はそれをマ イコンボードの回路図から探し出す. 教師は, そこに つながっている線をたどるように指導する。片側はた いてい電源がグラウンド（基準電位）につながってい て, 行き止まりである。もう一方は，たどっていくと， 必ずマイコンのポートにたどり着く，そこには，たと えばP71などという記号が記載されている.

ではP71とは何か. 洞察力のある学生は, ここでマイ コンのマニュアルを調べる必要性に気づく，気づかな い学生には, 教師が「“マイコンの” P71ですよね?」と いった簡単なヒントを出す，マイコンのマニュアルの 必要性に気づいた学生は, 容易にマニュアルをダウン ロードする，彼らはすでに，マイコンというものに関 する必要な情報を得る方法を学んでいるからである.

スイッチが接続しているポートがわかると, 今度は, スイッチを押したときの論理は何かが問題になる。本 コースの実施時には，スイッチのポートとは反対側の 行き止まりにある記号について，教師が説明をした。 つまりそれは, 電源 $(+)$ なりグラウンド $(0 \mathrm{~V})$ なり であるという内容である。

学生は, 中学高校の理科で電気回路を学んではいる ので, 理解力のある学生はこのヒントでスイッチ押下 時の論理を理解できる。 そうでない学生には, どうす ればよいかを議論させる。彼らは，実際に押下してみ てプログラムで読んでみればよいといったアイデアを 考案したりするので，教師は実行を勧める。すでに開
発環境はインストール済みなので, 学生は容易に試す ことができる。このように,「試しにやってみる」とい う方法を知ることも, 学び方を学ぶことのひとつと言 える.

次に学生はLEDの接続を調べる。これも記号は簡単 に調查できる.しかし, 今回 LED はマイコンボード上 にはなく, マイコンボードに接続したユニバーサル基 板上に実装してある (図 3 左側)。そして,この拡張部 分の回路図は用意していない. まったくのオリジナル 回路であるため, インターネットでの検索も役に立た ない.

ここで教師は，対象をよく観察してみましょうとだ けヒントを与える。実はこの拡張部分は, 図 7 のよう に配線がむき出しになっており, 目で追えるようにな っている.

すでに未知の回路図でも, 線を追えばマイコンへの 接続がわかることを学んでいる学生は, それが印刷し た線でなく, 実際の電線であっても同様であることを 理解できる. そして実物の回路の電線と, ボードの回路 図の線を追い, LEDがつながっているマイコンの端子 を探し出す。ここでも，スイッチのとき同様に, LED の点灯論理は何かが問題になるが，やはりスイッチの とき同様, ある学生はLEDのマイコンとは反対側の接 続を調べて推察し, またある学生は実際に該当するポ 一トに值を書き込んで調べる，それぞれが，基本を押 さえつつ自分なりの理解の方法を身につけていること を, 見て取れる.つまり, 学び方を学んだこと（によ る応用）を，すぐに確認できるしくみである.

\section{6. 実施結果}

我々はこれまでに，2012年に16名，2013年に20名の 大学院 1 年生に, この教育を実施した。学習時間は, 1 回あたり 90 分 $\times 15$ コマ=1350分の集中講座である.

課題のプログラムについては, 2012年は16名全員が, 2013年は20名中18名が基本要求仕様について完成に至 った（2名は不具合が残った）

図 8 に, 受講後に実施したアンケート結果の一部を 示す. 自由形式の記述項目で,「本コースへの感想」, 「自力での資料調査を重要視しましたがどうでしたか」 と,「ペアで作業したことはどうでしたか」という $3 つ$ の問いへの回答を集計したものである.グラフ中の数 值は,いずれも人数を示す．重複回答も計数している.

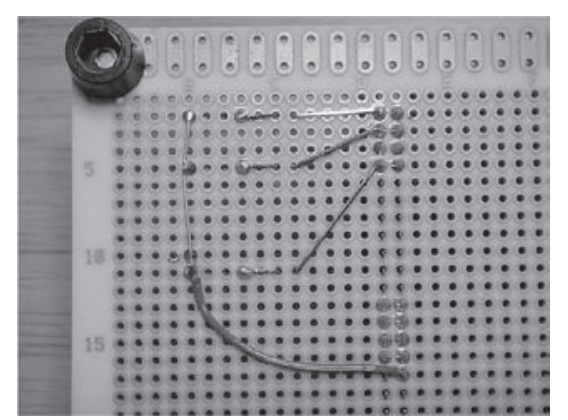

図 7 拡張部分のLEDの配線 
-対象者 : 本コース受講学生

2012年度16名, 2013 年度 20 名

一調査日：2012年 9 月 7 日，2013年 9 月 27 日

一調查方法：アンケート用紙を配布して記入

- 回答項目：全 9 項目中, 自由形式の 3 項目

\section{7. 考察}

我々は 2 章で目標行動を設定したが， 2 年間で 36 名 中34名が自力で開発を完遂できており，また自由形式 で記述された本コースへの感想に, この目標行動に合 致した行動が29名の回答に見られた.これは, 本授業計 画が全くの間違いではなかったことを示唆している. 課題プログラムの完成率から, 難易度も適切であった と考えている。，一方で，社会的スキルや技術的スキル に関する問題点が浮かび上がった.

自由形式の質問の中で, 自力での資料調査について の感想を求めたところ, 肯定的な意見が 24 件, とまど いの意見が 7 件，否定的な意見が 9 件あった，肯定的 意見は自力で調べることでより身についたと回答して いる学生が多かった。一方でとまどいや否定的な意見 は, さらなるヒントや指導を求めるものが多く, 分か らない事への不安が見られる。

今回のアンケートでは, 各学生の行動特性尺度を調 べていないため, この差が各学生の元来持つ行動特性 の差であるのか, 授業方法によるものであるかの判断 が難しいが, 何かしらの改善が必要である.

また，本論文では触れなかったが，本コースでは 2 名のペア（一部 3 名）で学習を行った。このことに関 し，「ペアを組んで作業したことはどうでしたか?」と いう質問に対しては，扔扮む敉肯定的な回答が多かっ たが，8名がとまどい，または否定的な回答であった。 この 8 名の回答内容もまた，社会的行動に価值を置い ていない意見が見られるという意味で共通している.

質問や相談などの社会的かつ主体的行動は, 自分の 能力を超えた分野に対する効率的な学習には不可欠で ある.よって，今後分からないときにどのような行動 を取れば良いかという社会スキルについて体験できる ミニゲームなどを取り入れるなどのカリキュラムを組

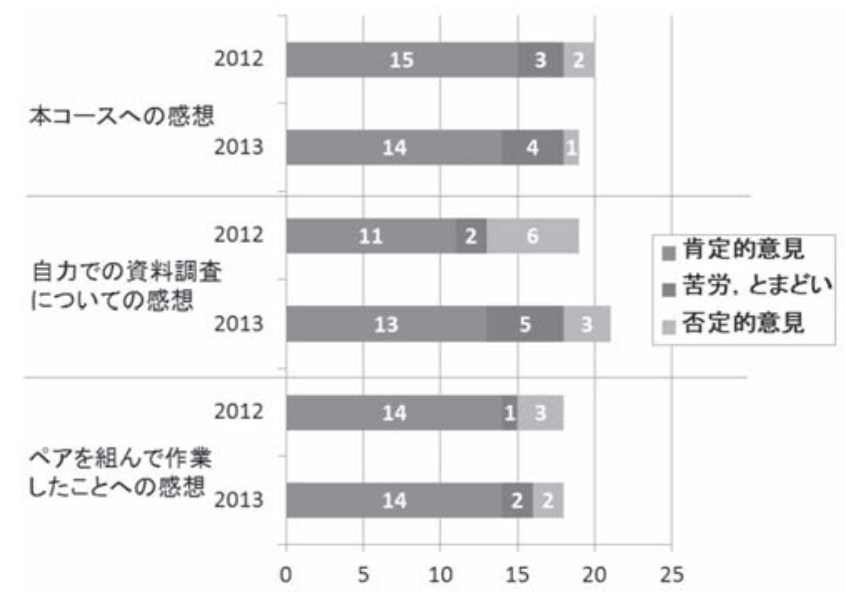

図 8 自由形式記述の集計結果
み达むことで,より良い結果になることが予想される. また技術スキル面では, 否定的意見を書いた学生は, 肯定的意見を書いた学生よりも，前提条件としている プログラミング・スキルが低いことが，授業の観察か らわかっている.

ペアでの学習についても,ペア間のプログラミング. スキルの差が大きい場合に, 否定的意見が出やすいこ とが, 同様に授業の観察からわかっている.

以上のことから，本コースのような技術教育への参 加学生には，プログラミング・スキルに関してなんら かの事前チェックが必要と考えられる. 少なくともぺ アを組むにあたっては, そのチェック結果を考慮すべ きであり，次回実施から対策する予定である.

\section{8.おわりに}

本研究の試行結果から, 知識を教えるのではなく, 問題解決に必要なルールや手順を自ら編み出す能力を 鍛えること，つまり学び方を学ばせる教育について， 可能性が見いだせたと考えている.

今後, 考察に述べた改善点等を工夫し, より効果的 な教育方法をさらに研究していく予定である.

\section{参 考 文 献}

1）経済産業省 商務情報政策局：IT化の進展と我 が国産業の競争力について, 2007年, Webページ, http : //www.meti.go.jp/committee/materials/ downloadfiles/g70313a03j.pdf, 参照日 : 2014-5-1

2 ）経済産業省 商務情報政策局 情報処理振興課: 2010年版組込みソフトウェア産業実態調查報告書, 事業責任者向け調査

3 ）中島聡: 中島聡の「端境期を生きる技術屋たちへ」, エンジニアtype, 2014, Webページ, http : // engineer.typemag.jp/article/nakajima-16, 参照 日 : 2014-5-1

4) 鈴木克明 : 教材設計マニュアル, 北大路書房, 2002

5 ）田中康一郎, 花野井歳弘: ハードウェアの知識を持 つ組达みソフトウェア技術者の育成プログラム, 九州産業大学情報科学会誌, $7-1,2008$

\section{著 者 紹 介}

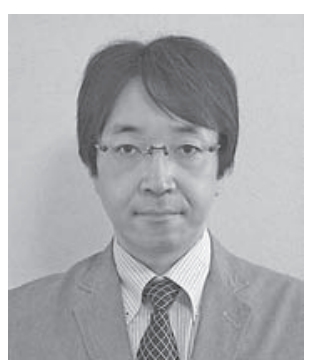

舘 伸幸

2012年ルネサスマイクロシステム株式会 社退社

同年, 名古屋大学組込みシステム研究セン 夕ー勤務

文部科学省「分野地域を越えた実践的情報 教育協働ネットワーク」組込み分野の名古 屋大学事業に従事中 